\title{
Preoperative core temperatures in elective surgical patients show an unexpected skewed distribution
}

\section{[Les températures centrales préopératoires affichent une distribution asymétrique}

inattendue chez les patients de chirurgie élective]

Andrew M. Mitchell BSc MBCHB DCH DIP OBS, R. Ross Kennedy MBCHB PHD FANZCA

Purpose: To document the preoperative core temperature of adult elective surgical patients.

Methods: A prospective audit obtained sublingual temperatures from 446 adult elective surgical patients on arrival in the preoperative holding area.

Results: Temperatures ranged from $35.7^{\circ} \mathrm{C}$ to $37.8^{\circ} \mathrm{C}$ with a mean of $36.5^{\circ} \mathrm{C}(0.4 \mathrm{SD})$. The median was $36.4^{\circ} \mathrm{C}$ and the mode was $36.1^{\circ} \mathrm{C}$. There was a skewed distribution with a clustering of values at the lower end of the range. All recordings were within the accepted normothermic range.

Conclusion: The asymmetric distribution we observed differs from previously published normothermia data which shows a symmetrical distribution of temperatures. This skewed distribution has not previously been documented and we interpret it as being due to the effect of preoperative cooling factors.

Objectif : Documenter la température centrale préopératoire de patients adultes en chirurgie élective.

Méthode : Un audit prospectif a fourni les températures sublinguales de 446 patients adultes en chirurgie élective au moment de leur arrivée à l'unité préopératoire.

Résultats: Les températures allaient de $35,7^{\circ} \mathrm{C}$ à $37,8^{\circ} \mathrm{C}$ selon une moyenne de $36,5^{\circ} \mathrm{C}$ (écart type de 0,4 ). La médiane a été de 36,4 ${ }^{\circ} \mathrm{C}$ et le mode a été de $36,1^{\circ} \mathrm{C}$. II y a eu une distribution asymétrique et un regroupement des valeurs à l'extrémité inférieure de la distribution. Toutes les valeurs enregistrées se situaient à l'intérieur d'un intervalle normothermique accepté

Conclusion : La distribution asymétrique observée differe des données normothermiques publiées antérieurement et qui montraient une distribution symétrique des températures. Cette distribution asymétrique n'a pas été documentée antérieurement et nous croyons qu'elle résulte de l'effet de facteurs de refroidissement préopératoire.
1 reduction in perioperative core temperature is a very common occurrence in surgical patients. The effects of even mild intraoperative hypothermia include increased blood transfusion, ${ }^{1-3}$ myocardial events, ${ }^{4,5}$ wound infection ${ }^{6}$ and prolonged hospital stay. ${ }^{3,6}$ Intraoperative temperature changes due to anesthetic, surgical and environmental factors and the mechanisms responsible are well documented. ${ }^{7-11}$

If patient core temperatures are low preoperatively then this may be a contributing factor to the subsequent development of intraoperative hypothermia. However, information on preoperative patient temperature $^{1,4-6,12}$ is limited. The aim of this audit was to document the distribution of preoperative core temperatures of surgical patients.

\section{Materials and methods}

After institutional approval a prospective audit was undertaken. Sublingual temperatures were recorded preoperatively in 446 adult elective surgical patients during July and August 1999 (winter) in Christchurch Hospital, New Zealand. All data were collected between 08:00 and 16:00 on weekdays. Data collection was coordinated by the holding bay charge nurse. Recordings were obtained on $93 \%$ of elective patients in the audit period.

Temperatures were obtained with a single Welch Allyn Suretemp thermistor thermometer (Welch Allyn Inc., San Diego, U.S.A.). This thermometer uses disposable probe covers over a sublingual temperature probe. The probe is placed orally in the sublingual pocket and a temperature is recorded when the machine detects sustained pressure against the sublin-

From the Department of Anesthesia, Christchurch Hospital, Christchurch, New Zealand.

Address correspondence to: Dr. A.M. Mitchell, Department of Anesthesia, Christchurch Hospital, Riccarton Avenue, Private Bag 4710 , Christchurch, New Zealand. Phone/Fax: 006403 3655446; E-mail: andrewmitchell@xtra.co.nz

Accepted for publication May 8, 2001.

Revision accepted July 9, 2001. 
gual tissue for four seconds. This ensures that the temperature is obtained from the sublingual tissue not intra-oral air. The instrument was supplied new and had been calibrated by the manufacturer with a stated accuracy of $\pm 0.1^{\circ} \mathrm{C}$ over a range of $28.9^{\circ} \mathrm{C}$ to $42.2^{\circ} \mathrm{C}$.

Sublingual temperature was recorded within a few minutes of arrival in the operating theatre holding bay. Patient demographic and surgical information were also recorded. The mean outdoor air temperature during the audit was $6.5^{\circ} \mathrm{C}$ with a mean daily range of $1.5^{\circ} \mathrm{C}$ to $11.4^{\circ} \mathrm{C}$ and an absolute range of $-4.2^{\circ} \mathrm{C}$ to $19^{\circ} \mathrm{C} .13,14$ The ward temperatures were thermostatically controlled to a set point of $22.0^{\circ} \mathrm{C}$.

Mean, median, mode and standard deviation were calculated.

\section{Results}

Data was obtained on 446 patients, 236 female and 210 male. The age range was 16 to 93 yr. The patients came from nine surgical wards. The largest single group (119 patients) was from the day surgical ward.

The range of temperatures was $35.7^{\circ} \mathrm{C}$ to $37.8^{\circ} \mathrm{C}$ with a mean of $36.5^{\circ} \mathrm{C}$ and a standard deviation (SD) of $0.4^{\circ} \mathrm{C}$. The median was 36.4 and the mode was $36.1^{\circ} \mathrm{C}$ (71 patients). The frequency distribution of core temperature recordings is shown in the Figure. This graph shows an asymmetric distribution about the mean. The data was also separated into 327 inpatients and 119 day surgical patients. Results for the 327 inpatients for temperature range, mean, median, mode ( 55 patients) and standard deviation were identical to that of the whole sample. The skewed pattern of frequency distribution seen in the Figure remained unchanged. Results for the 119 day surgical patients also closely followed this pattern with identical mean, median and standard deviation. The mode was 36.4 (17 patients) with a range of $35.9^{\circ} \mathrm{C}$ to $37.7^{\circ} \mathrm{C}$.

\section{Discussion}

Mild perioperative hypothermia is a common and potentially preventable occurrence in surgical patients. There is now clear evidence from randomized prospective trials that perioperative core temperatures of $1-3^{\circ} \mathrm{C}$ below normal are associated with serious adverse patient outcomes. These problems include increased blood loss, ${ }^{1,2}$ postoperative myocardial events ${ }^{4,5,15}$ and wound infections. ${ }^{6,9}$ Anesthetic recovery time is extended ${ }^{3,16}$ with a longer overall hospital stay. ${ }^{6}$ Mild hypothermia can also cause distress to patients through feeling cold and shivering. ${ }^{6,12}$

The etiology of perioperative hypothermia is multifactorial. The contribution of intraoperative anesthetic, surgical and environmental factors is well

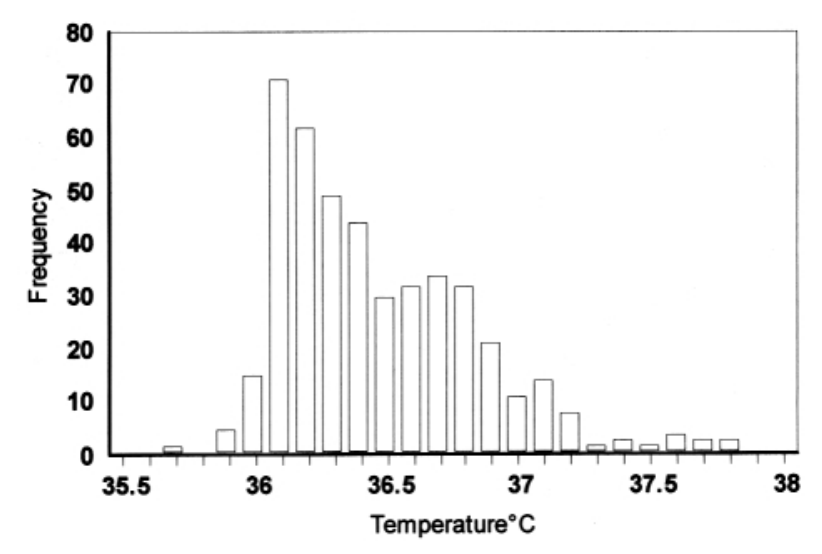

FIGURE Frequency distribution of preoperative sublingual temperature recordings in 446 adult elective surgical patients in Christchurch Hospital. The mean temperature is $36.5^{\circ} \mathrm{C}$.

documented. ${ }^{7-11}$ However, information on the contribution of preoperative temperature is limited. ${ }^{1,4-6,12}$ In our clinical practice we have observed that patients often feel cold on arrival in the anesthetic room. This led to the hypothesis that preoperative core temperatures may already be low prior to surgery. The goal of this audit was to document the distribution of preoperative core temperatures of surgical patients to see if low preoperative core temperatures were potentially a contributing factor to perioperative hypothermia in our hospital.

Our sample of 446 patients is the largest published assessment of preoperative core temperature and, to our knowledge, it is the only paper that analyzes the distribution of temperatures. Other published data consist of mean temperatures as part of prospective trials on the effects of perioperative hypothermia. Our audit found a mean preoperative core temperature of $36.5^{\circ} \mathrm{C}(0.4 \mathrm{SD})$. All recorded temperatures were within the accepted normothermic range ${ }^{17}$ which did not support our hypothesis that patients may have significantly hypothermic core temperatures prior to surgery. The notable new observation in this audit was the asymmetric distribution of temperatures within the range.

The mean temperature in our audit was at the lower end of published data on preoperative patient core temperatures. Kurz et al. ${ }^{6}$ in a study of $200 \mathrm{col}-$ orectal surgery patients recorded a mean preoperative tympanic temperature of $36.8^{\circ} \mathrm{C}(0.4 \mathrm{SD})$. Just et al..$^{12}$ followed 16 total hip arthroplasty patients and recorded a mean preoperative tympanic temperature of 
$36.5^{\circ} \mathrm{C}(0.4 \mathrm{SD})$. Frank et $a l^{4}$ studied 100 lower limb vascular surgical patients divided into two groups and found mean preoperative sublingual temperatures of $36.6^{\circ} \mathrm{C}(0.7 \mathrm{SD})$ and $36.5^{\circ} \mathrm{C}(0.7 \mathrm{SD})$.

In a study to find the means and limits of the normal body temperature Mackowiak et al. ${ }^{17}$ used 700 sublingual measurements in 148 healthy adult volunteers aged between 18-40 yr. This study reconfirmed the diurnal variation pattern where core temperature reaches its nadir of $36.4^{\circ} \mathrm{C}(0.4 \mathrm{SD})$ at $06: 00$ rising to a peak of $36.9^{\circ} \mathrm{C}(0.4 \mathrm{SD})$ at $16: 00-18: 00$. The range of normothermia was found to be between $35.6^{\circ} \mathrm{C}$ to $38.2^{\circ} \mathrm{C}$. The range of our data is similar with recordings of $35.7^{\circ} \mathrm{C}$ to $37.8^{\circ} \mathrm{C}$. This audit collected temperatures between 08:00 and 16:00. Averaging the Mackowiak et $a l .{ }^{17}$ data for the times where data was collected for this audit gave a mean expected normal temperature of $36.7^{\circ} \mathrm{C}(0.4 \mathrm{SD})$ for this audit. This is slightly higher than our observed mean of $36.5^{\circ} \mathrm{C}(0.4 \mathrm{SD})$.

The major difference between our data and that of Mackowiak is in the distribution of recorded temper atures within the range. Mackowiak's normothermia data is symmetrically distributed about the midpoint of the range with a mean and median of $36.8^{\circ} \mathrm{C}$ and a mode of $36.7^{\circ} \mathrm{C}$. This is the most common pattern for the distribution of biological variables. Our data showed a distinctly asymmetric distribution (Figure) with a clustering of values around $36.1^{\circ} \mathrm{C}$ to $36.4^{\circ} \mathrm{C}$ (mode $36.1^{\circ} \mathrm{C}$, median $36.4^{\circ} \mathrm{C}$ ). The asymmetric distribution was seen in both the 327 inpatients and the 119 day surgical patients. If the asymmetric distribution was seen only in the day surgical patients it would have suggested that recent exposure to cold external environmental temperatures may have biased the data. However, the asymmetric distribution was seen in both the inpatient and day surgical patients suggesting that hospital environmental factors are likely to be important in accounting for our findings.

Despite the surgical wing of our hospital being fully insulated, air conditioned and only ten years old, patients are exposed to a variety of preoperative factors that could cool them. A separate audit in our hospital found that $60 \%$ of patients were transported to the operating theatre uncovered, on top of their beds. Other cooling influences include travel to the hospital, ward temperatures of around $22^{\circ} \mathrm{C}$, thin single layer surgical clothing and transport down long cool corridors. Core temperature in an individual is tightly regulated by thermoregulatory mechanisms. ${ }^{18}$ However, one explanation for the asymmetric temperature distribution found in this audit would be that exposure to moderate cooling influences lowered the core temperature in many of our patients to their threshold for activation of heat conservation mechanisms. This occurs at around $36^{\circ} \mathrm{C}^{18}$ and would limit further core temperature reduction and prevent the development of overt hypothermia. This explanation is consistent with our observation of a cluster of patients at the lower end of the normothermic range.

This audit assessed the preoperative core temperature of elective surgical patients and a skewed distribution was seen. Further investigation is warranted to document this phenomenon elsewhere and to assess its significance with regard to subsequent intraoperative temperature changes.

\section{Acknowledgements}

We would like to thank Shona Pettengill and the holding bay nursing staff for their assistance with the collection of data for this audit. We would also like to thank Welsh Allyn for donating a thermometer for the duration of the audit. We are also grateful for the assistance of Deidre Keast with statistical analysis and Richard French with editing.

\section{References}

I Schmied H, Kurz A, Sessler DI, Kozek S, Reiter A. Mild hypothermia increases blood loss and transfusion requirements during total hip arthroplasty. Lancet 1996; 347: 289-92

2 Schmied H, Schiferer A, Sessler DI, Meznik C. The effects of red-cell scavenging, hemodilution, and active warming on allogenic blood requirements in patients undergoing hip or knee arthroplasty. Anesth Analg 1998; 86: 387-91.

3 Bock M, Müller J, Bach A, Böhrer H, Martin E, Motsch $J$. Effects of preinduction and intraoperative warming during major laparatomy. Br J Anaesth 1998; 80: 159-63.

4 Frank SM, Beattie C, Christopherson R, et al. Unintentional hypothermia is associated with postoperative myocardial ischemia. Anesthesiology 1993; 78 : $468-76$.

5 Frank SM, Fleisher LA, Breslow MJ, et al. Perioperative maintenance of normothermia reduces the incidence of morbid cardiac events. A randomized clinical trial. JAMA 1997; 277: 1127-34.

6 Kurz A, Sessler DI, Lenhardt R. Perioperative normothermia to reduce the incidence of surgical-wound infection and shorten hospitalization. N Engl J Med 1996; 334: 1209-15.

7 Sessler DI. Temperature monitoring. In: Miller RD (Ed.). Anesthesia, $4^{\text {th }}$ Ed., New York: Churchhill Livingston, 1994: 1369-74.

8 Sessler DI. Perioperative heat balance. Anesthesiology 2000; 92: 578-96. 
9 Sessler DI. Mild perioperative hypothermia. N Engl J Med 1997; 336: 1730-7.

10 Dhar P. Managing perioperative hypothermia. J Anesth 2000; 14: 91-7.

11 Holdcroft A, Hall GM, Cooper GM. Redistribution of body heat during anaesthesia. A comparison of

halothane, fentanyl and epidural anaesthesia.

Anaesthesia 1979; 34: 758-64.

12 Just B, Trevien V, Delva E, Lienhart A. Prevention of intraoperative hypothermia by preoperative skin- surface warming. Anesthesiology 1993; 79: 214-8.

13 New Zealand Climate Digest. National Institute of Water and Atmospheric Research Limited. July 1999.

14 New Zealand Climate Digest. National Institute of Water and Atmospheric Research Limited. August 1999.

15 Frank SM, Higgins MS, Breslow MJ, et al. The catecholamine, cortisol, and hemodynamic responses to mild perioperative hypothermia. Anesthesiology 1995; 82: 83-93.

16 Lenhardt R, Marker E, Goll V, et al. Mild intraoperative hypothermia prolongs postanesthetic recovery. Anesthesiology 1997; 87: 1318-23.

17 Mackowiak PA, Wasserman SS, Levine MM. A critical appraisal of $98.6 \mathrm{~F}$, the upper limit of the normal body temperature, and the other legacies of Carl Reinhold August Wunderlich. JAMA 1992; 268: 1578-80.

18 Ganong WF. Central regulation of visceral function. In: Ganong WF (Ed.). Review of Medical Physiology 19 ${ }^{\text {th }}$ ed., San Francisco: Lange, 1999: 239-43. 